\title{
Cultivating Students' Professional Ability in English Teaching in Higher Vocational College
}

\author{
Fan Zhang \\ Jiangxi Modern Polytechnic College
}

\begin{abstract}
Keywords: Higher vocational colleges; English teaching; Vocational ability; Curriculum reform; Practicality
\end{abstract}

\begin{abstract}
Nowadays, the demand of talented person for society is more and more intense, and the higher vocational colleges need make the goal to train the student's professional ability to find the usability of English study. This paper is based on the target of higher vocational college curriculum reform, the English Teaching in Higher Vocational Colleges under the condition of problems in training around the students occupation ability is analyzed briefly to further promote the curriculum reform of higher vocational education, and to enhance students' English application ability.

Along with the process of global economic integration, China and the world are becoming more and more closely linked. In order to introduce more advanced scientific technology, and to attract more investment from abroad to promote national development from technology and economy, it is necessary to promote college English teaching reform, cultivating students' occupation ability and improving students' English application ability to make the students better adapt to the needs of the times.
\end{abstract}

\section{What is Professional Ability}

In essence, professional ability refers to the ability of practitioners in order to qualify for a profession which can be professional ability or combination of multiple abilities.

For higher vocational colleges, vocational ability is the important goal of cultivating students. English education in school needs to base on practice to cultivate practical talents with both knowledge and ability. With the English teaching in higher occupation college, the students will be able to in the school of English used flexibly in the work requirements, perfectly competent work units after graduation to staff, so as to better adapt to the development of the local economy, the occupation demand and have a better future.

\section{Why to Cultivate Vocational College Students' English Ability}

The necessity of Cultivating Vocational College Students' English Ability. First of all, the cultivation of Vocational College Students' English ability is the requirement of the market. In Chinese, not every student will be admitted to the institution of higher learning and training, therefore, higher vocational colleges has become the best place for many students' proficiency in a particular line. In order to make the students in higher vocational colleges have more competitive, it must strengthen the students' ability of applying English, so as to make the students have strong practical ability and the ability of cross-cultural

Secondly, the cultivation of Vocational College Students' English professional ability is the requirement of the times. With the development of the world and the fusion of the times, English has not only professional proficiency in a particular line, and instead of the basic skills, modern people get better development which is necessary tool of communicating with the world.

Finally, the cultivation of Vocational College Students' English ability is determined by the characteristics of English. Like Chinese, English is language and then it is a subject. Therefore, the practicality of English Teaching in the process must be put in the first place.

Present situation of English Teaching in Higher Vocational Colleges.

No Innovation in Teaching Concept. Many teachers just teach for working, their orientation to English Teaching in Higher Vocational Colleges lack the necessary understanding which is not for 
students in the teaching process of targeted guidance, resulting in students' English learning only stay in the test with no application and development of a higher level, so that students cannot have English practical ability and lack of academic certificates, and they will be gradually phased out of the market

The Old Teaching Mode. Restricted by the traditional teaching mode, many high school English teachers in the teaching process is still around the textbooks on the vocabulary and grammar and text to highlight the teacher as the center of the class in the classroom which can take up a lot of time on the knowledge points to explain that do not leave the students practice time, making students become the giant and the application test on the dwarf, and many students even passed the English four and six level, but also cannot use English to communicate with people of normal, not to mention the foreign business.

Teaching Content without Personality. At present, most of the higher vocational colleges' English teaching in China is still large classes, no matter what professional English teaching has similar content, and the work point is very low. The teaching content and students' School of the future may engage in the work of almost no contact, no outstanding practical characteristics causing students to feel learn useless, not really will learn English in mind which leads students' efficiency is generally low, and English ability cannot get real exercise, in this case, the employer will not accept it.

Teaching Level is Still Lagging Behind. At present, the higher occupation colleges' teachers have uneven level, some teachers are satisfied with the status, but not on the teaching research, and they also not to carry out training, the daily teaching just cause the teaching level far echo what the books say not qualified for their teaching work, and this cannot adapt to the current social development and cultivate excellent students to market demand.

\section{How to Cultivate Students' Professional Ability in English Teaching in Higher Vocational School}

School: find their own positioning. Higher vocational school is different from the ordinary colleges and universities which provide students with higher academic qualifications, no more powerful teachers, and the only another way is laying a solid foundation in the practical aspects of teaching and occupation. Therefore, higher vocational colleges need to pinpoint their in order not to loss outweighs of the gain.

Promote the Reform of English Curriculum. Over the years, higher vocational English has been as the National English three or four, six level of test as teaching basic of English teaching, which are almost all around the examination and have ignored the target -- the practical ability and application. To some extent, the English Teaching in higher vocational colleges is out of the market demand. Higher vocational colleges must promote the curriculum reform to find their own position, and make the English curriculum more practical in order to help students get better employment.

Firstly, higher vocational English teaching should be make promoting the students' employment oriented to practical English level as the goal, and the examination oriented education into the application of education, occupation and improve the English application ability of students to make students more adapt to the needs of society, not find a job after graduation. Secondly, the higher vocational English teaching should set for curriculum reform, and the curriculum should post more fit for students in the hope that the occupation to the students' English targeted teaching, such as secretarial, logistics, tourism, hotel management and so on.

Integrating Teaching Content, Professionalism English Teaching. In English, each profession, each occupation, even each work will have some very professional terminology, for English as a second language for Chinese students, professional nouns in various areas in all recognize is almost impossible. Therefore, it is very necessary to carry out English Teaching in the major of Higher Vocational education.

Higher vocational colleges need to change teaching in large class teaching mode, according to the different professional students for students in English teaching, using different teaching to make students learn professional terminology in the field in a shorter period of time, and to better serve 
the day after work. When the students in the English class feel the practicality of English rather than formal, for their own future, students will work hard to learn English. For example, in the future, they will be engaged in professional secretarial work who can open letters, document writing course. And in the future, they will be engaged in the work of the professional computer, computer language can offer some special English courses to make students more relaxed in the future work.

In addition, because at this stage, students learning English is mostly about some partial daily life, and what is not too useful for students, after the occupation planning, therefore higher vocational colleges need to fully integrate the teaching contents, and the teaching of English is linked to future occupation combined with the English proficiency of students to enhance the teaching strength of oral English class, so that each student can speak English in the classroom and get further training of English application ability.

Improve The Quality of Teachers, Specialize English Knowledge. Teachers are the basis for the survival and development of Higher Vocational colleges. As if the teacher wants to give students a glass of water, then he must have a bucket of water in order to develop a good student, and high-quality teachers are essential. Because of this, in order to make the English Teaching in higher vocational schools to a higher level to cultivate more talents with ability of occupation, it must be equipped with a team of high-quality teachers and make more professional knowledge of English.

It is very simple to improve the quality of teachers. Firstly, the school can recruit a group of experienced teachers. Many veteran teachers still love teaching work in Higher Vocational Colleges after retirement if they can be hired, and it also let the lack of experience of the teachers learning from lectures, and teachers in teaching strengths to be improved for their own use to improve the teaching ability of teachers as a whole. Secondly, the school can be trained on the existing school teachers, and support teachers to postgraduate, and even abroad charge to make teachers have a higher educational level. Finally, the school can also introduce a number of high-end talents, in order to promote the construction and development of teaching and research team and to enhance the core competitiveness of the school.

Teachers: Everything for Students. With the orientation of higher vocational teaching, the teachers in higher vocational colleges must grasp the main task of teaching, all the students can find a job after graduation line, so teachers should help students improve their English application ability.

Innovative Teaching Methods. For a long time, English teaching is very simple, echo what the books say on the podium at the podium, and the students thought as chatters without stop, and with uncertain learning, all of the students will play which leads to the extremely low efficiency of classroom teaching. Therefore, higher vocational English teachers must change ideas, innovative teaching methods, make students become the real subject of classroom and increase classroom interaction with using a variety of teaching methods (such as communication method, case method and task method, simulation method, multimedia assisted method and so on.)to stimulate students' interest in learning, to enable students in the classroom to have close contact with the future occupation, and the foundation for the students' occupation ability will lay more solid.

Improve Student Cognition. Vocational college students are in the growth stage of life, although the thought is not mature, but has a preliminary cognitive ability. Therefore, to higher vocational students, teachers need to be treated like adults to help students to recognize the significance of English occupation ability in the future work and life, and to enable students to fully exert their initiative to learn which plays multiplier effect in school.

\section{Conclusion}

To sum up, higher vocational education itself determines the starting from the reality to the application oriented teaching mode, therefore, the transformation process of the demand for talents from the academic type to type in the market, and higher vocational education should play their own advantages, and in the course of English teaching, this can strengthen the cultivation of students' occupation ability in order to improve the students' employment ability to help students better in the face of life after graduation. 


\section{References}

[1] Xiaoyan Shi, Discussion on English teaching model based on vocational ability training in Higher Vocational College [J].Journal of Shanxi Normal University (Social Sciences Edition), 2014, S5: 247-248.

[2] Xiuping Yang Research on the reform of English teaching in Higher Vocational College based on the improvement of students' professional ability[J].Journal of Zhejiang Shuren University (Humanities and Social Sciences Edition),2013,04:91-96.

[3] Xiaoyi Hua. Exploration of English curriculum reform in Higher Vocational College based on Cultivating professional ability [J]. Journal of Changzhou College of Information Technology, 2015, 05:50-52. 